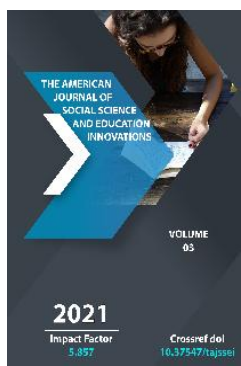

\title{
The Problem Of The Study Of The Lexical-Semantic Field Of "Time" In Linguistics
}

Shorasulova Arofat Ibroxim Qizi

Teacher, National University Of Uzbekistan, Tashkent, Uzbekistan

Journal Website:

http://theamericanjour

nals.com/index.php/taj

ssei

Copyright: Original content from this work may be used under the terms of the creative commons attributes 4.0 licence.

\section{ABSTRACT}

This scientific work analyzes the objective, subjective signs of time and their ways of expression: lexical and phraseological units in the temporal space, their place, scope, lexical units of time in the Uzbek language. There has been a great deal of research in the field of lexical semantics in linguistics, and scholars differ on this point. It is well known that in linguistics, the theory of the lexical-semantic field has been studied within one language, two languages, and based on comparative analysis.

\section{KEYWORDS}

Lexical units, modern Turkology, the lexical-semantic field of the concept, structural semantics and conceptual semantics.

\section{INTRODUCTION}

The scientific literature which is collected during the study of the lexical-semantic field of the concept of "time" is divided into three groups according to their content: the category of scientific works organized by Uzbek, Turkish and Russian linguists. In Uzbek 
linguistics, for example, Hakimova Muhayyo Karimova's dissertation for the degree of Candidate of Philological Sciences on "Lexical units of time in the Uzbek language and their possibilities of text formation" [1] contains a large number of important issues which were analyzed and synthesized on the category of time. M.V. Ergasheva's article "Linguistic view of the universe and its division into semantic fields" [2] is important because it provides a detailed analysis of the concepts of semantic space. According to her, the study of linguistic units by dividing them into semantic fields is a branch of semantics, and this field is a collection of semantic units that have similarities which are noted in this or that semantic layer, and are associated with specific semantic relationships.

\section{THE MAIN PART}

The presence of linguistic semantics, such as structural semantics and conceptual semantics, facilitates the study of language units on a field-by-field basis. It is said that the introduction of the "field theory" into Uzbek linguistics, is connected with the introduction of system-structural methods in relation to language units. M.F. Kurbanova in her dissertation "Semantic analysis of semantic lexical units "ma'naviyat" in the Uzbek language" [3] noted that the term 'semantic field' was formed under the influence of Western linguistics, but in our language during the Zoroastrian period words were divided into the semantic field. However, "field of meaning" was not recognized. If we focus, for example, on the words used in Zoroastrianism, we can divide these words into two types of systems of meaning. If we include words that have the meaning of good in the first field of view, we can divide others into words that have the meaning of evil in the field of the second meaning. The study focuses on the semantics of "ma'naviyat" (spirituality) and the human factor in its formation, i.e. the explanation of the anthropocentric theory. In this article, the semantic content of the semantics of "ma'naviyat" and the units with the semantics of "ma'naviyat" (spirituality) are identified and analyzed. During the analysis, the units with the "ma'naviyat" (spirituality) semaphore are grouped according to certain integral and differential features, and the units with the "ma'naviyat" (spirituality) semaphore are explained as much as possible.

Turkish linguistics also focuses on the semantic field too. In Z.Jangabilova's, and E.Hamitova's article "Türk ve kazak dillerinde fiil kökenli antroponimlerin leksik-semantik özelliği” [4] the lexical-semantic structure of verb anthroponyms in Turkish and Kazakh languages was analyzed. It is well known that the origin of verb pronouns is due to the fact that verbs and their lexical forms have nouns. In linguistics, lexical construction refers to word formation and semantic construction refers to word meaning. In the process of analysis, the lexical-semantic grouping of verb bases on anthroponyms in the Turkish and Kazakh languages, first in terms of meaning, and then the history of their emergence. In the article of Lamiye Vagifkizi "Çağdaş tük ve azerbaycan dillerinde kullanılan öztürkçe kelimelerin leksik-semantik özellikleri" [5] one of the problems which were studied, is the language process in modern Turkology. In the process of analysis, the researcher considers the characteristics of words used in Turkish and Azerbaijani languages, and their lexicalsemantic relations, terms and interaction. Currently, citizens of the independent 
Republic of Azerbaijan can use Turkish words without any restrictions. For example, durum, yayım, önem, soyadı, soydaş, yetersay, özelleştirmek, ateşkes, açıklama, destek, desteklemek, bilgisayar, soykırım, gecekondu, başarı, and other words are being generally used. As it given in the article of Murat Uluoğlu "Kalaç" kelimesinin türkçede ve rüsçede leksik semantik özellikleri ve kullanım alanları" [6] turkish dialects played an important role in enriching the vocabulary of the Russian language. Many words used in everyday life in Russian are considered to be borrowed from Turkish dialects. It is noteworthy that some Russian bread names have Turkish roots. But some of these words have also caused controversy. Because these words may have a specific history of etymological origin. In different sources, the origin of the word "kalaç" is proved by clear evidence that it is Turkish. Aynur Yetmen's doctoral dissertation "Zamanin felsefi temelleri üzerine bir inceleme" [7] the word "Time" is studied philosophically and is divided into three groups: 1. Biological time, that is, all the organs in the human body perform their functions in sequence, and this is called the biological clock. 2. Psychological time. 3. Physical time.

In S.G. Klyastorny's article “Eski türk yazıtlarında zaman ve mekan kavramı" [8] we can see that the first source to describe the way of life of the ancient Turks is the Chinese source Chou Shu, written in the 6th century $B C$ and describing the nomadic people living in the north as a "primitive gang". It says that the Turks used the colour of the plants, instead of the calendar, to calculate the time. Moreover, the epigraphic monuments of the ancient Turks were used by the Turks in various other ways to determine the time. In other words, the Sogdian inscriptions in Bugut, the only surviving monument of the first Turkish khanate, indicate the use of the "twelve animal" calendar. It was a "solar calendar" that divided the year into 12 months.

In Russian linguistics, this issue is also covered in the following works too. According to the doctoral dissertation of L.N.Muheeva "Vremja $v$ russkoj jazykovoj kartine mira: lingvokulturologicheskij aspekt" [9] at the beginning linguistics used to study time as a grammatical category which now it has been studied in the world as one of the elements of the linguistic landscape, a cultural concept that studies this or that nation from a linguocultural point of view, as a cognitive category. Time is a fundamental and universal category that reflects the various aspects of life, activity, consciousness, science, culture, language, and human life in general. Therefore, the time has long been the subject of study in various disciplines, but the concept of time remains a mystery to both humanity and science. In the dissertation of Yu.A.Kuznetsov "Leksiko semanticheskoe pole smeha kak fragment russko jazykovoj kartiny mira" [10] main attention was given to study the lexical-semantic field of the concept of "laughter" in modern Russian from a linguocultural point of view and to determine that the lexeme "laughter" as a concept. In the lexical system of the language, the lexicalsemantic field of the concept of "laughter" is studied as a result of the analysis of emotions, facial expressions, loudness, and gestures.

\section{CONCLUSION}

To sum up, this concept is interpreted differently in works devoted to the study of 
the lexical-semantic field in linguistics. Taken together, they can be divided into two major groups. The scholars in the first group regard the class of equally valuable linguistic units combined based on a particular meaning as a semantic field. At this point, the field becomes linguistic: in common with the paradigm. Therefore, they try to differentiate between the concepts of semantic field and paradigm concepts and take different hierarchy and one hierarchy as a differential sign between the two concepts. If applied only to the lexical level, the paradigm can be used to almost all level units. In this case, the concept of paradigm includes both a class of lexemes combined based on a certain common meaning and a class of syntaxes, as well as a class of phonemes united based on a certain general sign. The second group of scholars, on the other hand, uses the same hierarchy and different hierarchy as the differential sign between the paradigm, the semantic field, and the different levels, but apply this sign to the relationship between the members of the paradigm and the field.

\section{REFERENCES}

1. Khakimova M.K. (2004). Uzbek lexical units and their possibilities of text formation. (Dissertation which was written for taking PhD) Fergana.

2. Ergasheva M.V. (2016). Linguistic landscape and division of the world into semantic fields. Molodoy uchenyy. No.3.1. S. pp.59-62.
3. Kurbonova M.F. (2014). Semantic analysis of semantic lexical units "spirituality" in the Uzbek language. Dissertation written for taking a Master's degree. T.

4. Jangabilova Z. (2000). Türk ve kazak dillerinde fiil kökenli antroponimlerin leksik-semantik özelliği [Lexicalsemantic feature of verb-origin anthroponym in Turkish and Kazakh languages]. Ankara. (in Turkish).

5. Lamiye Vagifkizi. (2008). Çağdaş tük ve azerbaycan dillerinde kullanılan öztürkçe kelimelerin leksik-semantik özellikleri [The lexical-semantic features of the Uz Turkish words used in contemporary Turkish and Azerbaijani languages]. Baku. (in Turkish).

6. Murat Uluoğlu. (2010). "Kalaç" kelimesinin türkçede ve rüsçede leksik semantik özellikleri ve kullanım alanları. Ankara [Lexical semantic features and usage areas of the word "Kalaç" in Turkish and Russian]. (in Turkish).

7. Aynur Yetmen. (2014). Zamanin felsefi temelleri üzerine bir inceleme. Doctora Tezi. Ankara [A review of the philosophical foundations of the time. Doctorate Thesis]. (in Turkish).

8. Klyaštorny, S. G. Eski türk yazitlarinda zaman ve mekân kavrami. Dil Araştırmaları [The concept of time and space in old Turkish inscriptions. Language Studies], 9(17), 247-251. (in Turkish). 
9. Mikheeva, L.N. (2004). Time in the Russian linguistic picture of the world: linguoculturological aspect. Moscow, 329.

10. Yu.A. Kuznetsov (2010). The lexicosemantic field of laughter as a fragment of the Russian-language picture of the world. Dissertation. Moscow. 